\title{
Rates of Soill Redistribution Associated with Soill Zones and Slope Classes in Southern Saskatchewan
}

\author{
D.J. PENNOCK and E. de JONG \\ Department of Soil Science, University of Saskatchewan, Saskatoon
}

\begin{abstract}
Using ${ }^{137} \mathrm{Cs}$ redistribution techniques we examined the relationship between mean rates of soil redistribution and average slope characteristics at twenty-one areas in the Brown, Dark Brown, and Black Chernozem soil zones of southern Saskatchewan. Net soil losses averaged $5.8 \mathrm{t} \mathrm{ha}^{-1} \mathrm{yr}^{-1}$ for areas with mean gradients between 0 and $1.5^{\circ}, 7.8 \mathrm{t} \mathrm{ha}^{-1}$ $\mathrm{yr}^{-1}$ for areas with mean gradients between 1.0 and $3^{\circ}$, and $11.3 \mathrm{tha}^{-1} \mathrm{yr}^{-1}$ for areas with mean gradients between 3.5 and $8.5^{\circ}$. For all three slope classes, the highest rates of soil loss were found in the Dark Brown soil zone and the lowest rates in the Black soil zone. Net soil loss alone was, however, an inadequate indicator of the rate of loss within the areas because a considerable proportion of eroded soil was deposited within the confines of the study areas.
\end{abstract}

\section{Introduction}

Considerable progress has been made by researchers using ${ }^{137} \mathrm{Cs}$ redistribution techniques in defining the association between small, uniform segments of hillslopes and rates of soil erosion and deposition. There is, however, a considerable disparity between this type of intensive examination of the slope-erosion relationship and the type of slope information available from the major source of soil-resource information in Canada: the provincial and federal soil surveys. We examined the relationship between soil redistribution and the average slope characteristics at 21 areas in the Brown, Dark Brown, and Black Chernozemic soil zones of southern Saskatchewan to determine whether different rates of erosion and deposition were associated with the average characteristics of the mapped units.

\section{Materials and Methods}

Seven geographical locations in the Brown, Dark Brown, and Black Chernozem soil zones of southern Saskatchewan were sampled in 1986 and 1987. Each geographical location was designated by the soil zone -- B for Brown, DB for Dark Brown, and BL for Black - and the first letter of the closest municipality. At each geographical location three 2- to 3-hectare study areas were chosen from soil survey maps: an area with slope class 1 or 2 (0 to $1.5^{\circ}$ slopes), an area with slope class 3 or 4 (1 to $3^{\circ}$ slopes), and an area with slope class 5 ( 3.5 to $8.5^{\circ}$ slopes). The slope class is indicated by a L (low), M (medium), or $\mathrm{H}$ (high) designation after the locational abbreviations outlined above (Table 1). All the medium- and high-slope areas were located in units mapped as hummocky or undulating terrain and all areas had been in a grain-fallow rotation since the 1930's. All areas except BAL and BSL were mapped as medium-textured, till-derived soils; areas BAL and BSL were variably textured, glacio-lacustrine soills. 
Table 1. Geographical description and mean slope morphology characteristics of study areas

\begin{tabular}{|c|c|c|c|c|c|c|}
\hline $\begin{array}{l}\text { Geographical } \\
\text { location }\end{array}$ & $\begin{array}{l}\text { Slope } \\
\text { group }\end{array}$ & $\begin{array}{l}\text { Site } \\
\text { label }\end{array}$ & $\begin{array}{l}\text { Number of } \\
\text { sample sites }\end{array}$ & $\begin{array}{c}\text { Gradient } \\
()^{\prime}\end{array}$ & $\begin{array}{c}\text { Profile } \\
\text { curvature }(\% / \mathrm{m})\end{array}$ & $\begin{array}{c}\text { Plan } \\
\text { curvature }(\% / \mathrm{m})\end{array}$ \\
\hline Stewart Valley & $\begin{array}{l}\text { Low } \\
\text { Medium } \\
\text { High }\end{array}$ & $\begin{array}{l}\text { BSL } \\
\text { BSM } \\
\text { BSH }\end{array}$ & $\begin{array}{l}23 \\
30 \\
28\end{array}$ & $\begin{array}{l}1.1 \pm 0.5 t \\
1.4 \pm 0.8 \\
3.9 \pm 2.1\end{array}$ & $\begin{array}{c}0.04 \pm 0.07 \ddagger \\
2.09 \pm 1.50 \\
-0.02 \pm 0.12\end{array}$ & $\begin{array}{l}-1.80 \pm 2.3 \ddagger \\
-0.50 \pm 3.8 \\
-1.00 \pm 3.1\end{array}$ \\
\hline Assiniboia & $\begin{array}{l}\text { Low } \\
\text { Medium } \\
\text { High }\end{array}$ & $\begin{array}{l}\text { BAL } \\
\text { BAM } \\
\text { BAH }\end{array}$ & $\begin{array}{l}20 \\
24 \\
31\end{array}$ & $\begin{array}{l}1.4 \pm 0.8 \\
2.5 \pm 1.4 \\
3.9 \pm 2.0\end{array}$ & $\begin{array}{r}0.01 \pm 0.03 \\
-0.01 \pm 0.14 \\
0.03 \pm 0.22\end{array}$ & $\begin{array}{r}-0.09 \pm 1.8 \\
-0.14 \pm 4.4 \\
0.49 \pm 4.6\end{array}$ \\
\hline Viscount & $\begin{array}{l}\text { Low } \\
\text { Medium } \\
\text { High }\end{array}$ & $\begin{array}{l}\text { DBVL } \\
\text { DBVM } \\
\text { DBVH }\end{array}$ & $\begin{array}{l}36 \\
36 \\
36\end{array}$ & $\begin{array}{l}0.5 \pm 0.3 \\
2.5 \pm 1.1 \\
4.3 \pm 2.0\end{array}$ & $\begin{array}{r}0.03 \pm 0.17 \\
-0.01 \pm 0.16 \\
-0.01 \pm 0.27\end{array}$ & $\begin{array}{r}-0.10 \pm 4.1 \\
0.71 \pm 4.9 \\
-0.23 \pm 3.9\end{array}$ \\
\hline Chester & $\begin{array}{l}\text { Low } \\
\text { Medium } \\
\text { High }\end{array}$ & $\begin{array}{l}\text { DBCL } \\
\text { DBCM } \\
\text { DBCH }\end{array}$ & $\begin{array}{l}36 \\
36 \\
36\end{array}$ & $\begin{array}{l}1.8 \pm 0.9 \\
2.0 \pm 1.2 \\
2.1 \pm 1.1\end{array}$ & $\begin{array}{l}0.01 \pm 0.10 \\
0.01 \pm 0.23 \\
0.01 \pm 0.18\end{array}$ & $\begin{array}{l}0.44 \pm 5.1 \\
0.23 \pm 3.5 \\
0.52 \pm 5.1\end{array}$ \\
\hline Stoughton & $\begin{array}{l}\text { Low } \\
\text { Medium } \\
\text { High }\end{array}$ & $\begin{array}{l}\text { DBSL } \\
\text { DBSM } \\
\text { DBSH }\end{array}$ & $\begin{array}{l}36 \\
36 \\
36\end{array}$ & $\begin{array}{l}1.2 \pm 0.8 \\
2.4 \pm 1.3 \\
3.4 \pm 1.8\end{array}$ & $\begin{array}{l}-0.03 \pm 0.13 \\
-0.05 \pm 0.13 \\
-0.03 \pm 0.17\end{array}$ & $\begin{array}{r}-1.10 \pm 5.1 \\
1.80 \pm 3.4 \\
4.61 \pm 0.3\end{array}$ \\
\hline Foam Lake & $\begin{array}{l}\text { Low } \\
\text { Medium } \\
\text { High }\end{array}$ & $\begin{array}{l}\text { BLFL } \\
\text { BLFM } \\
\text { BLFH }\end{array}$ & $\begin{array}{l}36 \\
36 \\
36\end{array}$ & $\begin{array}{l}0.9 \pm 0.5 \\
1.9 \pm 1.1 \\
2.7 \pm 1.5\end{array}$ & $\begin{array}{l}-0.03 \pm 0.11 \\
-0.03 \pm 0.13 \\
-0.04 \pm 0.27\end{array}$ & $\begin{array}{r}-0.27 \pm 5.4 \\
-0.74 \pm 4.8 \\
1.41 \pm 6.5\end{array}$ \\
\hline Hafford & $\begin{array}{l}\text { Low } \\
\text { Medium } \\
\text { High }\end{array}$ & $\begin{array}{l}\text { BLHL } \\
\text { BLHM } \\
\text { BLHH }\end{array}$ & $\begin{array}{l}36 \\
36 \\
71\end{array}$ & $\begin{array}{l}0.4 \pm 0.3 \\
1.0 \pm 0.7 \\
3.9 \pm 2.5\end{array}$ & $\begin{array}{r}-0.04 \pm 0.03 \\
0.01 \pm 0.08 \\
0.19 \pm 0.76\end{array}$ & $\begin{array}{c}-0.02 \pm 4.8 \\
1.19 \pm 6.92 \\
0.13 \pm 5.39\end{array}$ \\
\hline
\end{tabular}

TMean and standard deviation.

$\ddagger$ Positive values are convex, negative values are concave. 
At each study area a rod-and-transit topographic survey was completed. At study areas in the Brown Chernozem soil zone an $8 \times 4$ grid was used for sampling. The grid can be envisaged as four parallel transects of 8 sample points, with a constant spacing of $25-\mathrm{m}$ between the transects and the sample points in the transects. Interference with humanmade features lead to the loss of sample points from these grids, and a $6 \times 6$ grid with 25-m spacings was adopted for sampling in the Dark Brown and Black Chernozem zones. Fifteen-centimeter-long soil samples were removed from 7.2-cm diameter cores extracted by a truck-mounted hydraulic drill at each site. The soils were sampled to $45 \mathrm{~cm}$ if the $\mathrm{Ah} / \mathrm{Ap}$ horizon was thinner than $45 \mathrm{~cm}$ and to the Cca horizon at sites with Ah/Ap horizons thicker than $45 \mathrm{~cm}$.

A regularly spaced digital terrain model was generated for each study area from the irregularly spaced topographical observations using the Surface II mapping program. The digital terrain models were calculated with a 10 -m spacing between interpolated elevations for an area which included the soil sampling grid and a 50-m fringe around the grid. Using programs developed by Martz (1986) we then calculated gradient $\left(^{\circ}\right.$ ), plan (across-slope) curvature $(\% \mathrm{~m})$, and profile (downslope) curvature $(\% / \mathrm{m})$ for each interpolated point on the digital terrain model.

The ${ }^{137} \mathrm{Cs}$ concentrations of each sample site were measured using the gamma spectroscopy techniques discussed by de Jong et a. (1982). The ${ }^{137} \mathrm{Cs}$ concentration $\left(\mathrm{Bq} \mathrm{m} \mathrm{m}^{-2}\right.$ ) of each 15-cm-long core sample was used in combination with the bulk density of the core to calculate soil loss or gain using the procedure given in Pennock and de Jong (1987). For sites where the ${ }^{137} \mathrm{Cs}$ concentration of the 0 - to 15 -cm segment exceeded that of the uncultivated sites (Riss et al. 1988), the soil gain was calculated as a fraction of the 5-cm segment below the 10-cm cultivation layer. The rate of soil loss or gain at each site was calculated by dividing the total soil loss or gain in tonnes per hectare by the number of years elapsed since peak ${ }^{137} \mathrm{Cs}$ fallout in 1963.

The ${ }^{137} \mathrm{Cs}$ concentrations from uncultivated sites which were used to establish the original ${ }^{137} \mathrm{Cs}$ input were gathered as part of a province-wide assessment of ${ }^{137} \mathrm{Cs}$ concentrations in non-cultivated soils (Kiss et al. 1988). The uncultivated site concentration used in our study was the mean concentration of the three closest samples (within $20 \mathrm{~km}$ ) to our sampling area. The rates of soill loss or gain discussed subsequently in our study are relative to these native site concentrations and are subject to the assumptions discussed in de Jong et al. (1982, 1983).

The rates are reported for each sampled area, for areas grouped by slope class (low, medium, or high) and for areas grouped by soil zone (Brown, Dark Brown, and Black). The rates assessed for each study area were expressed in three ways: net soil movement (the mean of soil loss or gain based on all sample sites at the area), mean soil loss (the mean of those sample sites within each area which had experienced soil loss), and mean soil gain (the mean of those sample sites within each area which had experienced soil gain). Additionally, the percentage of sampling stations within each study area which experienced soill loss or soil gain are reported. Because an unbiased, regularly spaced sample design was used, these percentages indicate the areal extent of each area which had experienced loss or gain. Comparisons between the means of areas grouped by slope class and by soil zone were conducted using the Least Significant Difference test. 


\section{Results}

The mean slope gradients of all but three study areas were within the range of slope gradients for the mapped slope class as outlined in the Canadian System of Soil Classification (Canada Soil Survey Committee 1978) (Table 1). Significant differences were observed between the areas grouped by slope class in terms of mean gradient. The mean plan and profile curvatures of both the individual areas and areas grouped by slope class were close to 0 and no significant differences were observed between the three slope classes (Table 2).

Table 2. Mean, standard deviation, and mean comparisons for slope morphology associated with slope class

\begin{tabular}{lcccc}
\hline \hline $\begin{array}{l}\text { Slope } \\
\text { class }\end{array}$ & $\mathrm{N}$ & $\begin{array}{c}\text { Gradient } \\
(9\end{array}$ & $\begin{array}{c}\text { Plan } \\
\text { curvature }\end{array}$ & $\begin{array}{c}\text { Profile } \\
\text { curvature }\end{array}$ \\
\hline Low & 223 & $1.0 \pm 0.8 \mathrm{a}$ & $-0.4 \pm 4.5 \mathrm{a}$ & $0.00 \pm 0.11 \mathrm{a}$ \\
Medium & 234 & $2.0 \pm 1.2 \mathrm{~b}$ & $0.4 \pm 4.7 \mathrm{a}$ & $0.00 \pm 0.15 \mathrm{a}$ \\
High & 274 & $3.5 \pm 2.1 \mathrm{c}$ & $0.2 \pm 4.7 \mathrm{a}$ & $0.00 \pm 0.44 \mathrm{a}$
\end{tabular}

Means in the same column with the same letter are not significantly different from each other (LSD, $\alpha=0.05)$.

Eighteen of the twenty-one study areas experienced a net loss of soil since 1963 (Table 3). Eleven areas experienced net soil losses between 0 and $10 \mathrm{t} \mathrm{ha}^{-1} \mathrm{yr}^{-1}$ and seven experienced net losses in excess of $10 \mathrm{t} \mathrm{ha}^{-1} \mathrm{yr}^{-1}$. Of the three areas which experienced net soil gains two were in the low-slope class and one was in the medium-slope class. Considerable dispersion of values for net soil movement was evident (Table 3). The dispersion of values about the mean was lowest for the areas in the low-slope group and highest for the high-slope group areas.

The net soil loss or gain values understate the erosion and deposition which had occurred within the individual study areas. At 19 of the study areas the majority of sampling stations had lost soil since 1963 and soil deposition was generally concentrated in a small percentage of the sampling stations (Table 3 ). Considering only that part of the sampling area which had experienced erosion, two areas experienced mean soil losses between 0 and $10 \mathrm{tha}^{-1} \mathrm{yr}^{-1}, 11$ areas had mean soil losses between 10 and $20 \mathrm{t} \mathrm{ha}^{-1} \mathrm{yr}^{-1}$, six areas had mean losses between 20 and $30 \mathrm{t} \mathrm{ha}^{-1} \mathrm{yr}^{-1}$, and two areas had mean losses in excess of $30 \mathrm{tha}^{-1} \mathrm{yr}^{-1}$. At nine of the sites the mean soil gain ranged from 0 to $10 \mathrm{tha}^{-1}$ $\mathrm{yr}^{-1}$, four sites showed gains of 10 to $20 \mathrm{tha}^{-1} \mathrm{yr}^{-1}$, four gained 20 to $30 \mathrm{tha}^{-1} \mathrm{yr}^{-1}$, and four of the deposition areas gained over $30 \mathrm{t} \mathrm{ha}^{-1} \mathrm{yr}^{-1}$. 
Table 3. Summary of soil redistribution at each study area

\begin{tabular}{|c|c|c|c|c|c|}
\hline Site & $\begin{array}{l}\text { Net soil } \\
\text { movement }\end{array}$ & 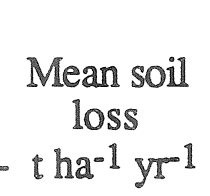 & $\begin{array}{l}\text { Mean soil } \\
\text { gain }\end{array}$ & $\begin{array}{l}\text { Sampling } \\
\text { stations with } \\
\text { soil loss }\end{array}$ & $\begin{array}{l}\text { Sampling } \\
\text { stations with } \\
\text { soil gain }\end{array}$ \\
\hline BSL & $0.5 \pm 7.3^{t}$ & $6.0 \pm 4.7$ & $5.5 \pm 4.6$ & 43.3 & 56.7 \\
\hline BSM & $-5.7 \pm 21.6$ & $16.7 \pm 11.4$ & $20.9 \pm 17.1$ & 56.7 & 43.3 \\
\hline $\mathrm{BSH}$ & $-7.5 \pm 29.4$ & $27.2 \pm 17.4$ & $18.9 \pm 19.7$ & 57.1 & 42.9 \\
\hline BAL & $-16.3 \pm 11.6$ & $20.6 \pm 8.4$ & $1.1 \pm 0.6$ & 56.7 & 43.3 \\
\hline BAM & $-6.5 \pm 13.9$ & $14.8 \pm 9.3$ & $8.9 \pm 4.6$ & 65.2 & 34.8 \\
\hline $\mathrm{BAH}$ & $-13.9 \pm 21.9$ & $25.8 \pm 15.7$ & $9.7 \pm 10.3$ & 66.7 & 32.3 \\
\hline DBVL & $-8.9 \pm 8.3$ & $10.9 \pm 7.2$ & $2.3 \pm 2.1$ & 83.3 & 16.7 \\
\hline DBVM & $-10.8 \pm 15.9$ & $17.8 \pm 12.5$ & $2.1 \pm 7.2$ & 72.2 & 27.8 \\
\hline DBVH & $-12.9 \pm 30.3$ & $24.1 \pm 13.8$ & $25.8 \pm 40.7$ & 77.8 & 32.2 \\
\hline $\mathrm{DBCL}$ & $-8.2 \pm 15.4$ & $17.5 \pm 10.3$ & $8.1 \pm 6.5$ & 63.9 & 36.1 \\
\hline $\mathrm{DBCM}$ & $-3.4 \pm 17.5$ & $15.4 \pm 6.4$ & $13.5 \pm 13.6$ & 55.6 & 44.4 \\
\hline $\mathrm{DBCH}$ & $-12.6 \pm 21.1$ & $20.1 \pm 12.3$ & $22.3 \pm 12.2$ & 80.6 & 19.4 \\
\hline DBSL & $-8.8 \pm 18.3$ & $18.8 \pm 12.3$ & $12.3 \pm 11.2$ & 69.4 & 30.6 \\
\hline DBSM & $-19.0 \pm 18.5$ & $22.3 \pm 12.9$ & $33.9 \pm 20.8$ & 94.4 & 5.6 \\
\hline DBSH & $-16.1 \pm 23.9$ & $24.2 \pm 11.6$ & $33.6 \pm 19.9$ & 86.1 & 13.9 \\
\hline DLFL & $5.2 \pm 20.3$ & $17.4 \pm 11.5$ & $12.7 \pm 16.6$ & 25.0 & 75.0 \\
\hline BLFM & $0.9 \pm 50.8$ & $30.9 \pm 21.9$ & $36.5 \pm 50.5$ & 52.8 & 47.2 \\
\hline BLFH & $-9.7 \pm 42.3$ & $33.0 \pm 21.9$ & $31.6 \pm 37.8$ & 63.9 & 36.1 \\
\hline BLIIL & $-6.3 \pm 6.7$ & $8.8 \pm 5.7$ & $1.3 \pm 2.1$ & 75.0 & 25.0 \\
\hline BLHM & $-9.4 \pm 12.7$ & $14.7 \pm 11.9$ & $1.9 \pm 2.7$ & 66.7 & 33.3 \\
\hline BLHIH & $-8.5 \pm 18.3$ & $18.4 \pm 19.8$ & $26.5 \pm 23.6$ & 78.9 & 21.1 \\
\hline
\end{tabular}

Mean and standard deviation.

Despite the variability of the results observed at the individual study areas, significant differences did occur between the areas grouped by soil zone and by slope class (Tables 4 and 5). Overall, sites in the Black soil zone experienced the lowest net soil losses and areas in the Dark Brown soil zone the highest, and the differences between the two zones were statistically significant (Table 4). The low-slope areas experienced the lowest net soil losses, mean soil losses and mean soil gains, and the high-slope areas the highest values for the three redistribution variables. The medium-slope areas occupied an intermediate position.

\section{Discussion}

The net movement experienced by individual study areas was a relatively poor indication of the rates of soil loss or gain within the areas. While only seven out of 21 areas had experienced net soil losses in excess of $10 \mathrm{tha}^{-1}$ yr 1,19 areas had experienced mean soil losses within the area in excess of $10 \mathrm{tha}^{-1} \mathrm{yr}^{1}$. Hence, while measurements of net soil movement may be of great importance in establishing the off-field impacts of soil erosion, in this study they were inadequate to document the on-field impacts. 
Table 4. Mean, standard deviation, and mean comparisons for soil redistribution for study areas grouped by soil zone

\begin{tabular}{lcccc}
\hline Soil zone & $\mathrm{N}$ & $\begin{array}{c}\text { Net soil } \\
\text { movement }\end{array}$ & $\begin{array}{c}\text { Mean } \\
\text { soil loss } \\
\mathrm{tha}^{-1} \mathrm{yr}^{-1}\end{array}$ & $\begin{array}{c}\text { Mean } \\
\text { soil gain }\end{array}$ \\
\hline Brown & 156 & $-8.2 \pm 20.3 \mathrm{ab}$ & $19.7 \pm 13.9 \mathrm{a}$ & $11.4 \pm 13.5 \mathrm{a}$ \\
Dark Brown & 324 & $-11.2 \pm 19.9 \mathrm{a}$ & $19.2 \pm 12.0 \mathrm{a}$ & $14.7 \pm 18.3 \mathrm{a}$ \\
Black & 251 & $-5.2 \pm 28.7 \mathrm{~b}$ & $18.6 \pm 15.8 \mathrm{a}$ & $19.1 \pm 30.4 \mathrm{a}$ \\
\hline
\end{tabular}

Means in the same column with the same letter indicate no significant difference exists between the means (LSD, $\alpha=0.05$ ).

Table 5. Mean, standard deviation, and mean comparisons for soil redistribution for areas grouped by slope class and for areas grouped by soil zone within slope classes

\begin{tabular}{|c|c|c|c|c|c|}
\hline $\begin{array}{l}\text { Slope } \\
\text { class }\end{array}$ & $\begin{array}{l}\text { Soil } \\
\text { zone }\end{array}$ & $\mathbb{N}$ & $\begin{array}{l}\text { Net soil } \\
\text { movement }\end{array}$ & $\begin{array}{l}\text { Mean } \\
\text { soil loss }\end{array}$ & $\begin{array}{l}\text { Mean } \\
\text { soil gain }\end{array}$ \\
\hline $\begin{array}{l}\text { Low } \\
\text { Medium } \\
\text { High }\end{array}$ & $\begin{array}{l}\text { All } \\
\text { All } \\
\text { All }\end{array}$ & $\begin{array}{l}223 \\
234 \\
274\end{array}$ & $\begin{array}{l}-5.8 \pm 15.1 a \\
-7.8 \pm 25.9 a b \\
-11.3 \pm 26.7 b\end{array}$ & $\begin{array}{l}14.0 \pm 9.9 \mathrm{a} \\
19.0 \pm 13.9 \mathrm{~b} \\
22.6 \pm 14.6 \mathrm{c}\end{array}$ & $\begin{array}{r}8.4 \pm 11.6 \mathrm{a} \\
17.5 \pm 29.0 \mathrm{~b} \\
23.6 \pm 25.2 \mathrm{~b}\end{array}$ \\
\hline $\begin{array}{l}\text { Low } \\
\text { Low } \\
\text { Low }\end{array}$ & $\begin{array}{c}\text { Brown } \\
\text { Dark Brown } \\
\text { Black }\end{array}$ & $\begin{array}{r}43 \\
108 \\
72\end{array}$ & $\begin{array}{l}-7.3 \pm 12.7 \\
-8.7 \pm 14.5 \\
-0.7 \pm 16.0\end{array}$ & $\begin{array}{l}14.9 \pm 10.2 \\
15.1 \pm 10.4 \\
10.9 \pm 8.3\end{array}$ & $\begin{array}{l}4.4 \pm 4.3 \\
8.5 \pm 18.7 \\
9.6 \pm 15.2\end{array}$ \\
\hline $\begin{array}{l}\text { Medium } \\
\text { Medium } \\
\text { Medium }\end{array}$ & $\begin{array}{c}\text { Brown } \\
\text { Dark Brown } \\
\text { Black }\end{array}$ & $\begin{array}{r}54 \\
108 \\
72\end{array}$ & $\begin{array}{r}-5.9 \pm 18.2 \\
-11.0 \pm 18.4 \\
-4.1 \pm 37.3\end{array}$ & $\begin{array}{l}15.8 \pm 10.3 \\
19.0 \pm 11.7 \\
21.3 \pm 18.8\end{array}$ & $\begin{array}{l}14.4 \pm 13.2 \\
12.8 \pm 13.4 \\
22.2 \pm 41.9\end{array}$ \\
\hline $\begin{array}{l}\text { High } \\
\text { High } \\
\text { High }\end{array}$ & $\begin{array}{c}\text { Brown } \\
\text { Dark Brown } \\
\text { Black }\end{array}$ & $\begin{array}{r}59 \\
108 \\
107\end{array}$ & $\begin{array}{r}-10.8 \pm 25.8 \\
-13.9 \pm 25.2 \\
-8.9 \pm 28.4\end{array}$ & $\begin{array}{l}26.4 \pm 16.2 \\
23.1 \pm 12.8 \\
20.4 \pm 15.7\end{array}$ & $\begin{array}{l}14.7 \pm 16.5 \\
26.5 \pm 27.5 \\
28.9 \pm 28.4\end{array}$ \\
\hline
\end{tabular}

Means in the same column with the same letter indicate no significant difference exists between the means (LSD, $\alpha=0.05$ ). 
The assessment of the overall severity of the observed rates of mean soill loss was hampered by the lack of an accepted value for tolerable soil loss for Saskatchewan soils. Several authors have used Wischmeier and Smith's (1978) range of 7.5 to $11.2 \mathrm{tha}^{-1} \mathrm{yr}^{-1}$ as a guideline for tolerable loss of Saskatchewan soils. Even if the upper limit of this range is adopted--which is generous considering the thinness of Ah horizons in these soils--the mean soil losses within the areas were for the most part in excess of the tolerable soil loss.

The disparities between net soil movement and mean soil loss were caused by the relatively high percentage of eroded soil which was deposited within the confines of the study areas. A disparity between mean soil loss within the area and net soil export from the area was also observed in a Black Chernozemic soil zone by Pennock and de Jong (1987). In both of these studies the majority of sampling sites within the study areas had experienced soil loss and the mean soil-loss rates within the field were two to five times larger than the net soill losses.

The means for the three soil redistribution variables had a large dispersion of values associated with them. The dispersion of values was lowest for the low-slope areas, both individually and as a group, and highest for the high-slope areas. The spatial disparities in the action of erosional and depositional processes on a hillslope will inherently cause large variances in any study that attempts to assess soil redistribution on an entire hillslope, rather than from individual, uniform slope segments within the hillslope. The high dispersion of values necessitates the use of a large number of sampling sites within an area if local or regional comparisons are to be made from the data.

Despite the range of soil redistribution values associated with individual study areas, significant differences were observed between areas grouped by slope class and by soil zone. The differences between areas grouped by slope class were consistent with the positive correlation which exists between mean slope gradient and soil erosion (Morgan 1986): the lowest net and mean soill losses were associated with the low-slope areas and the highest with the high-slope areas. Hence the results of our study indicate that the basic topographical information available from soil surveys would be useful in establishing preliminary rankings of the mapped soil units as to the impact of erosion.

The differences between the areas grouped by soil zone are less-readily explained. The lowest net soil losses were associated with the Black soil zone areas and the highest with the Dark Brown soil zone areas, and these differences were generally consistent in all three slope classes. The reasons for the differences between soil zones are not evident from our study.

\section{Summary and Conclusions}

The rates of mean soil loss within the study areas demonstrate that soil-erosion rates in excess of a tolerable loss rate were widespread. Net soil losses from the areas were generally a weak indicator of the severity of erosion within the areas because a considerable proportion of the eroded soil was deposited within the study areas, and this deposition was commonly concentrated in a small proportion of the sampling sites.

The differences observed between mean soil loss and net soil loss illustrate a major constraint to the use of predictive equations such as the Universal Soil Loss Equation in these areas. The USLE is limited to predicting the rate of erosion within an area of uniform slope and has no ability to calculate concomitant deposition within the area; yet the rate of deposition within an area was, in our study, a major factor controlling overall net soill loss. 
A more realistic estimator of soil redistribution by erosion and deposition should include terms for the topographic controls on deposition.

The rates of erosion, in terms of both net losses and mean losses, were highest for areas in the Dark Brown soil zone and lowest for areas in the Black soil zone. In all soil zones (Brown, Dark Brown, and Black) the highest rates of mean loss and mean gain were associated with areas which had mean slope gradients greater than $3^{\circ}$.

The differences observed between slope class and soil zones indicate that preliminary regional soil-erosion inventories can be constructed on the basis of the average slope gradients of the mapped areas. Once a mean rate of loss or gain has been determined for a given slope class a regional erosion inventory can be constructed by determining the areal percentage of the region occupied by soils within that slope class. Although such inventories would necessarily over-simplify the local variations between individual sites it would allow quantitative comparisons to be made between regions.

\section{Acknowledgements}

Field work for this project was assisted by $\mathrm{X}$. Hao and J. Kiss. Laboratory work was assisted by $\mathrm{H}$. Trotter and $\mathrm{K}$. Heidinger. The research was supported by a Strategic Grant from the Natural Sciences and Engineering Research Council.

\section{References}

Canada Soil Survey Committee, Subcommittee on Soil Classification. 1978. The Canadian system of soil classification. Can. Dep. Agric. Publ. 1676. Supply and Services Canada, Ottawa.

Coote, D.R., Dumanski, J. and Ramsey, J.F. 1981. An assessment of the degradation of agricultural lands in Canada. L.R.R.I. Contribution No. 118, Research Branch, Agriculture Canada, Ottawa.

de Jong, E., Villar, H. and Bettany, J. R. 1982. Preliminary investigations of the use of 137Cs to estimate erosion in Saskatchewan. Can. J. Soil Sci. 62:673-683.

de Jong, E., Begg, C.B.M. and Kachanoski, R.G. 1983. Estimates of soil erosion and deposition for some Saskatchewan soils. Can. J. Soil Sci. 63: 607-617.

Kiss, J. J., de Jong, E. and Martz, L.W. 1988. The distribution of fallout cesium-137 in southern Saskatchewan, Canada. J. Environ. Qual. 17: 445-452.

Morgan, R.P.C. 1986. Soil Erosion and Conservation. Longman Scientific and Technical Publishers, London.

Martz, L.W. 1986. Variability of net soil erosion and its association with topography in Canadian prairie agricultural landscapes. Ph.D. Thesis, Department of Geography, University of Saskatchewan, Saskatoon, Canada.

Martz, L.W. and de Jong, E. 1987. Using cesium-137 to assess the variability of net soil erosion and its association with topography in a Canadian prairie landscape. Catena 14: 439-451.

Pennock, D.J. and de Jong, E. 1987. The influence of slope curvature on soil erosion and deposition in hummocky terrain. Soil Sci. 144: 209-218.

Wischmeier, W H. and Smith, D.D. 1978. Predicting rainfall erosion losses: a guide to conservation planning. USDA-SEA Agriculture Handbook No. 537, U.S. Government Printing Office, Washington, D.C. 